\title{
Armstrong Landing Site (41CS37): An Ancestral Caddo Site on the Sulphur River, Cass County, Texas
}

Timothy K. Perttula

Heritage Research Center, Stephen F. Austin State University

Follow this and additional works at: https://scholarworks.sfasu.edu/ita

Part of the American Material Culture Commons, Archaeological Anthropology Commons, Environmental Studies Commons, Other American Studies Commons, Other Arts and Humanities Commons, Other History of Art, Architecture, and Archaeology Commons, and the United States History Commons

Tell us how this article helped you.

This Article is brought to you for free and open access by the Center for Regional Heritage Research at SFA ScholarWorks. It has been accepted for inclusion in Index of Texas Archaeology: Open Access Gray Literature from the Lone Star State by an authorized editor of SFA ScholarWorks. For more information, please contact cdsscholarworks@sfasu.edu. 


\section{Armstrong Landing Site (41CS37): An Ancestral Caddo Site on the Sulphur River, Cass County, Texas}

\section{Creative Commons License}

\section{(c) (1) (8)}

This work is licensed under a Creative Commons Attribution-NonCommercial 4.0 International License 


\title{
Armstrong Landing Site (41CS37): An Ancestral Caddo Site on the Sulphur River, Cass County, Texas
}

\author{
Timothy K. Perttula
}

\section{INTRODUCTION}

The Armstrong Landing site (41CS37) is an ancestral Caddo site on an alluvial terrace of the Sulphur River at Lake Wright Patman (Figure 1). It was formally recorded by Briggs and Malone (1970) prior to a planned enlargement of Lake Wright Patman. According to records on file at the Texas Archeological Research Laboratory, The University of Texas at Austin (TARL), collectors from the Texarkana area had worked the site in the early 1960s, digging four burials there and noting extensive midden deposits. The site remains above the normal conservation flood pool of the lake at present (Bonine et al. 2004:23; Dockall and Fields 2006), but is subject to erosion from wave action.

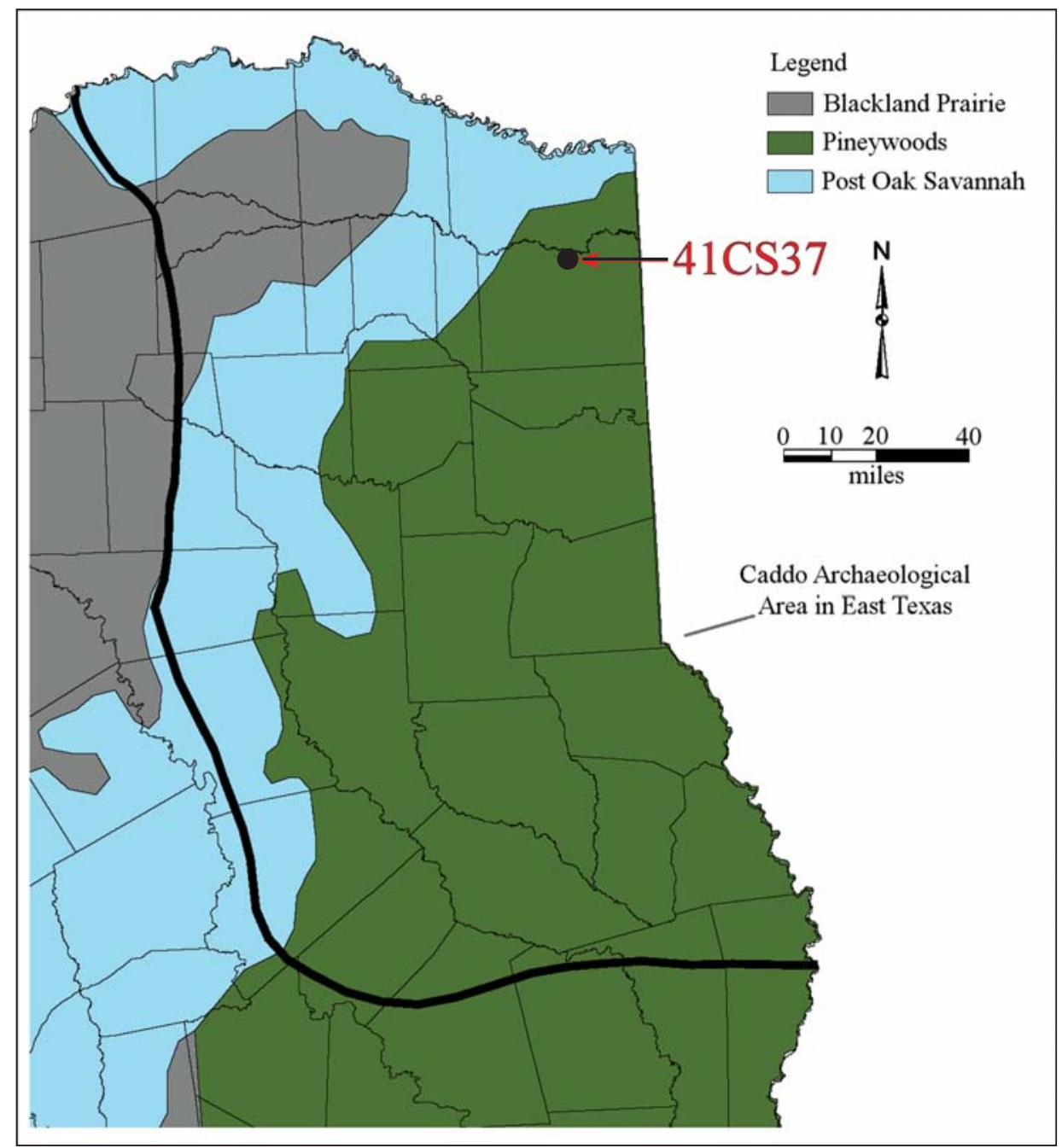

Figure 1. Location of the Armstrong Landing site (41CS37) in East Texas. 


\section{SITE INVESTIGATIONS}

In a 1966 letter from Janson McVay to TARL, he described the 1963 excavation of four ancestral Caddo burials at the Armstrong Landing site. The burials were encountered between ca. 91-102 cm bs. McVay's Burial 1 had a Nash Neck Banded jar as its sole funerary offering, and two of the burials are Historic Caddo period age. The one historic Caddo burial described by McVay was excavated by Paul Schoen and had more than 1000 glass beads, two iron clasp knives, a brass bracelet, and two ceramic vessels: an Emory PunctatedIncised bowl and a Natchitoches Engraved bowl.

It appears that the burial features described by McVay are the same burial features mentioned by Harris et al. (1980) from what they call the Atlanta State Park site, based on the similarities in the contents of the burial features, but Harris et al. (1980:232) note that the site was almost completely destroyed by the construction of a concrete boat ramp. The Armstrong Landing site as of 2006 was mostly intact, however, according to Bonine et al. (2004) and Dockall and Fields (2006). Thus, it is probable that the Armstrong Landing site and the Atlanta State Park site are two different, but nearby, sites with Historic Caddo burials.

Keeping the caveats just mentioned about there being two different sites in mind, McVay's Burial 1 may be the same as that described as Burial 3 in Harris et al. (1980:235), and it had two shell-tempered Nash Neck Banded jars; the deceased individual was in an extended supine position in the grave, with their head facing west. The Historic Caddo burial excavated by Paul Schoen may be the feature identified as Burial 2 in Harris et al. (1980:233); it was also placed in an extended supine position in a grave, and its head faced west. This burial had numerous funerary offerings: two shell-tempered ceramic vessels (Natchitoches Engraved and possible Emory Punctated-Incised, see Harris et al. 1980:Figure 1f-g), two iron knives, a brass bracelet, and 1258 glass beads. Most of the glass beads were small to medium-sized barrel-shaped and donut-shaped blue beads. Burial 1 in Harris et al. (1980:232) was in an extended supine position with the head facing west. Funerary offerings included a shell-tempered Emory Punctated-Incised jar and 583 glass beads. Almost all the glass beads are medium-sized barrel-shaped blue beads. Harris et al. (1980:235) suggests that these burials were Nasoni Caddo individuals, as the site is near the Portage of the Nassonites on the Sulphur River used by the Frenchman Benard de la Harpe in 1719.

In addition to the burials, Harris et al. (1980:237-238) excavated a $10 \mathrm{x} 2 \mathrm{ft}$. wide trench in the midden deposits west of the burials at what they referred to as the Atlanta State Park site. The midden appears to contain stratified archaeological deposits, as follows: ca. 36-76 cm bs, Woodland period dart points and lithic debris; ca. 33-36 cm bs, Coles Creek Plain and Coles Creek Incised sherds, likely from a brief ca. A.D. 900 occupation; $15-33 \mathrm{~cm}$ bs, Early and Middle Caddo period (ca. A.D. 1000-1400) ceramic sherds of the types Crockett Curvilinear Incised, Hickory Engraved, Haley Engraved, and Haley Complicated Incised; and $0-15 \mathrm{~cm}$ bs, probable Late and Historic Caddo period (ca. A.D. 1400-1740) archaeological deposits with shell-tempered Emory Punctated-Incised, Natchitoches Engraved, Avery Engraved, Simms Engraved, Nash Neck Banded, and McKinney Plain.

When Briggs and Malone (1970) recorded the site, they noted the evidence of the previous digging of burials - as described above - and extensive midden deposits. The site was estimated to cover a ca. 400 x $100 \mathrm{~m}$ of the alluvial terrace (ca. 10 acres), and a considerable number of artifacts, primarily ceramic sherds, were collected from the surface and cut banks at the site. Their 1970 collection is the collection I have analyzed in this article.

In 2004, the Armstrong Landing site was revisited by Bonine et al. (2004:21-24) in advance of proposed tree thinning activities by the Fort Worth District of the U.S. Army Corps of Engineers. Bonine et al. (2004:Figure 4-1) noted a large disturbed area near the shoreline that is evidence of previous digging by collectors. Bonine et al. (2004:22) excavated only four shovel tests at this large site, and when one shovel test was found to contain an unidentified bone fragment and a Caddo ceramic sherd, the crew inexplicably abandoned further shovel testing of the site on the orders of one of the Fort Worth District archaeologists (Bonine et al. 2004:24). The site has not been visited by professional archaeologists since then. 


\section{ARTIFACT ASSEMBLAGE}

The TARL artifact assemblage from the Armstrong Landing site primarily is comprised of ceramic sherds from ancestral Caddo ceramic vessels, including 133 decorated sherds. There also are two pieces of daub and a Late Archaic style Yarbrough dart point.

\section{Ceramic Sherds}

In addition to 450+ plain sherds (including several that may be from Williams Plain vessels, according to the TARL inventory) - which were not examined during this analysis of the collection-there are also 90 sherds from utility ware vessels and 43 sherds from fine ware vessels (Table 1). More than 86 percent of the sherds are from grog-tempered vessels - with comparable proportions in both the utility ware and fine ware-almost 13 percent are from bone-tempered vessels, and only one sherd ( 0.8 percent $)$ is from a shell-tempered vessel.

Table 1. Assemblage of decorated sherds from the Armstrong Landing site (41CS37).

\begin{tabular}{lcccccc}
\hline Ware & \multicolumn{2}{c}{ Grog } & Bone & Shell & N \\
& rim & body & rim & body & body \\
\hline Utility & 7 & 71 & 1 & 11 & - & 90 \\
Fine & 6 & 31 & - & 5 & 1 & 43 \\
\hline Totals & 13 & 102 & 1 & 16 & 1 & 133 \\
\hline
\end{tabular}

The sherds from utility ware vessels comprise 68 percent of the decorated sherd assemblage, as well as 57 percent of the decorated rim sherds. Almost half (49 percent) of the utility ware sherds are from vessels with incised decorative elements (Table 2), including rims with horizontal incised lines, diagonal incised lines, and diagonal opposed incised lines (Figure 2a-b). Another rim sherd with horizontal incised lines also is lip notched.

Table 2. Decorative methods and elements in the utility ware sherds from the Armstrong Landing site.

\begin{tabular}{lllll} 
Decorative method/ & \multicolumn{2}{c}{ Grog } & \multicolumn{2}{c}{ Bone } \\
Decorative element & Rim & Body & Body & N
\end{tabular}

\section{Appliqued}

straight appliqued fillet

straight appliqued ridge

$\begin{array}{lllll}- & 2 & - & 2 & 4 \\ - & 3 & - & - & 3\end{array}$

\section{Brushed}

opposed brushing marks

parallel brushing marks

$\begin{array}{rrrrr}- & 3 & - & - & 3 \\ - & 13 & - & 1 & 14\end{array}$

Brushed-Appliqued

parallel brushed-straight appliqued fillet

$\begin{array}{ll}- & 4\end{array}$


Table 2. Decorative methods and elements in the utility ware sherds from the Armstrong Landing site, cont.

\begin{tabular}{|c|c|c|c|c|c|}
\hline \multirow{2}{*}{$\begin{array}{l}\text { Decorative method/ } \\
\text { Decorative element }\end{array}$} & \multicolumn{2}{|c|}{ Grog } & \multicolumn{2}{|c|}{ Bone } & \multirow[b]{2}{*}{$\mathrm{N}$} \\
\hline & $\operatorname{Rim}$ & Body & Rim & Body & \\
\hline \multicolumn{6}{|l|}{ Brushed-Incised } \\
\hline $\begin{array}{l}\text { horizontal brushed and diagonal incised, } \\
\text { R-L, on the body }\end{array}$ & - & 1 & - & - & 1 \\
\hline parallel brushed-incised & - & 1 & - & 1 & 2 \\
\hline \multicolumn{6}{|l|}{ Brushed-Punctated } \\
\hline parallel brushed-fingernail punctated row & - & 1 & - & - & 1 \\
\hline \multicolumn{6}{|l|}{ Incised } \\
\hline diagonal lines, L-R & 1 & - & - & - & 1 \\
\hline $\begin{array}{l}\text { diagonal incised, L-R and vertical } \\
\text { incised on the body }\end{array}$ & - & - & - & 1 & 1 \\
\hline diagonal opposed lines & - & 2 & - & - & 2 \\
\hline horizontal lines & 5 & - & 1 & - & 6 \\
\hline opposed lines & - & 1 & - & - & 1 \\
\hline parallel lines & - & 24 & - & 4 & 28 \\
\hline straight line & - & 4 & - & 1 & 5 \\
\hline \multicolumn{6}{|l|}{ Incised-Lip Notched } \\
\hline horizontal lines and lip notched & 1 & - & - & - & 1 \\
\hline \multicolumn{6}{|l|}{ Incised-Punctated } \\
\hline $\begin{array}{l}\text { diagonal lines }(\mathrm{R}-\mathrm{L}) \text { above tool punctated } \\
\text { rows at rim-body juncture }\end{array}$ & - & 1 & - & - & 1 \\
\hline $\begin{array}{l}\text { horizontal and zoned incised with rows of } \\
\text { cane punctates in incised zone }\end{array}$ & - & 2 & - & - & 2 \\
\hline $\begin{array}{l}\text { horizontal lines above tool punctated row } \\
\text { at rim-body juncture }\end{array}$ & - & 4 & - & - & 4 \\
\hline $\begin{array}{l}\text { parallel incised lines on either side of a } \\
\text { zone of tool punctates }\end{array}$ & - & 1 & - & - & 1 \\
\hline \multicolumn{6}{|l|}{ Punctated } \\
\hline fingernail punctated rows & - & 1 & - & - & 1 \\
\hline tool punctated rows & - & 2 & - & 1 & 3 \\
\hline Totals & 7 & 71 & 1 & 11 & 90 \\
\hline
\end{tabular}

$\mathrm{L}-\mathrm{R}=$ left to right; diagonal lines begin at the left at the top of the rim and end at the right at the bottom of the rim; $\mathrm{R}-\mathrm{L}=$ right to left; diagonal lines begin at the right at the top of the rim and end at the left at the bottom of the rim

The appliqued sherds from the site (7.8 percent of the utility ware sherds) have straight appliqued fillets and appliqued ridges (see Table 2). These appliqued elements are on sherds from McKinney Plain jars where the vessel body was divided into a series of panels by vertical oriented appliqued fillets and ridges 


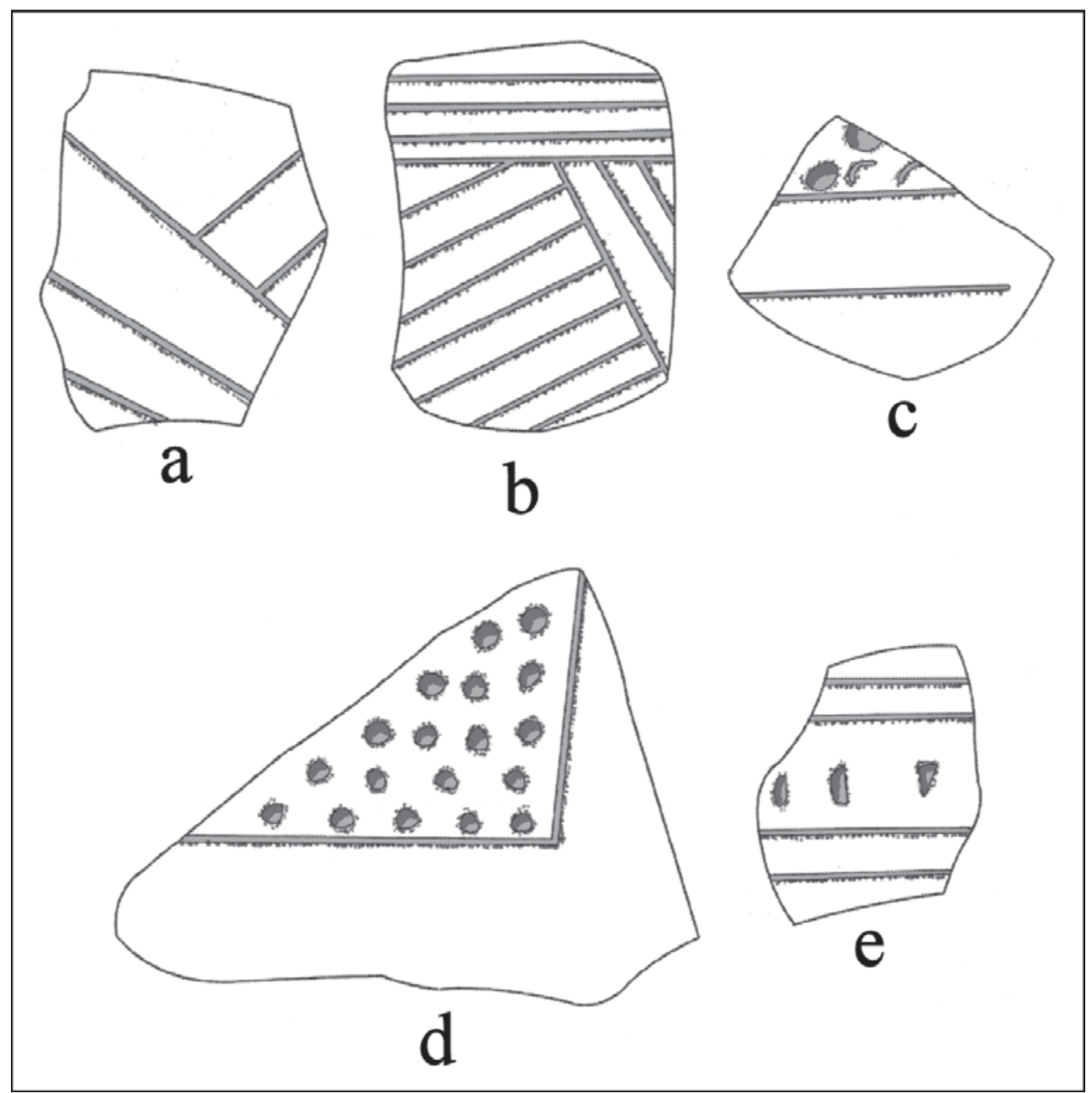

Figure 2. Selected decorative elements on utility ware sherds from the Armstrong Landing site (41CS37): a-b, incised body sherds; c-e, incised-punctated body sherds.

(see Suhm and Jelks 1962:97). Brushed sherds comprise almost 19 percent of the utility ware sherds from the Armstrong Landing site (see Table 2), and brushed-appliqued, brushed-incised, and brushed-punctated body sherds from probable Pease Brushed-Incised jars account for another 9 percent of the utility ware sherds.

The incised-punctated sherds ( 8.9 percent of the utility ware sherds) include two distinctive Early Caddo style Pennington Punctated-Incised body sherds with straight line incised zones filled with rows of cane punctations (see Figure 2d-e). The others have either rows of punctations at the rim-body juncture or are in zones defined by straight incised lines (see Table 2).

There are only a few body sherds (4.4 percent) with punctated elements in the Armstrong Landing site utility ware assemblage (see Table 2). These have either rows of tool or fingernail punctations.

The fine ware sherds from the Armstrong Landing site include sherds from both engraved (93 percent) and red-slipped (7 percent) vessels (Table 3); the red-slipped sherds are likely from bowls or carinated bowls. Only one of the engraved sherds is clearly from a bottle, a Haley Engraved bottle with horizontal lines on the vessel body and open pendant triangles (Figure $3 i$ ). 
Table 3. Decorative methods and elements in the fine ware sherds from the Armstrong Landing site.

\begin{tabular}{|c|c|c|c|c|c|}
\hline \multirow{2}{*}{$\begin{array}{l}\text { Decorative method/ } \\
\text { Decorative element }\end{array}$} & \multicolumn{2}{|c|}{ Grog } & \multicolumn{2}{|c|}{ Bone } & \multirow[b]{2}{*}{$\mathrm{N}$} \\
\hline & $\operatorname{Rim}$ & Body & $\operatorname{Rim}$ & Body & \\
\hline \multicolumn{6}{|l|}{ Engraved } \\
\hline curvilinear lines & - & 1 & - & - & 1 \\
\hline curvilinear, opposed, and horizontal lines & - & 1 & - & - & 1 \\
\hline $\begin{array}{l}\text { diagonal lines, } \mathrm{L}-\mathrm{R} \text {, and zones of } \\
\text { triangular tick marks }\end{array}$ & - & 1 & - & - & 1 \\
\hline diagonal opposed lines & - & 4 & - & - & 4 \\
\hline hatched zone & - & 1 & - & 1 & 2 \\
\hline hatched triangles & - & 3 & - & - & 3 \\
\hline horizontal and diagonal hatched zones & - & 1 & - & - & 1 \\
\hline horizontal, diagonal, and rectilinear lines & - & 1 & - & - & 1 \\
\hline horizontal engraved lines & 6 & 1 & - & - & 7 \\
\hline $\begin{array}{l}\text { horizontal engraved lines with hatched } \\
\text { pendant triangles }\end{array}$ & - & 1 & - & - & 1 \\
\hline $\begin{array}{l}\text { horizontal engraved lines with pendant } \\
\text { open triangles }\end{array}$ & - & 1 & - & - & 1 \\
\hline horizontal scroll element & - & 1 & - & - & 1 \\
\hline parallel lines & - & 9 & - & 2 & $12 *$ \\
\hline straight line & - & 2 & - & 1 & 3 \\
\hline vertical and rectilinear lines & - & - & - & 1 & 1 \\
\hline \multicolumn{6}{|l|}{ Red-Slipped } \\
\hline int./ext. red-slipped & - & 3 & - & - & 3 \\
\hline Totals & 6 & 31 & - & 5 & 43 \\
\hline
\end{tabular}

*also includes one shell-tempered body sherd with parallel engraved lines

$\mathrm{L}-\mathrm{R}=$ left-right; diagonal engraved line begins at the left at the top of the rim and ends at the right at the bottom of the rim

The other engraved sherds are likely from carinated bowls with decorative elements on the rim panel. All the rim sherds have horizontal engraved lines, and they may be from Hickory Engraved vessels (see Suhm and Jelks 1962:Plate 36g, j). Other sherds have hatched triangle elements (see Figure 3a, g), rows of hatched pendant triangles on horizontal engraved lines (see Figure 3f), horizontal and diagonal hatched zones (see Figure 3b), and sherds with portions of horizontal scroll elements (see Figure 3c-e). These latter sherds may be from Friendship Engraved carinated bowls (see Suhm and Jelks 1962:45). One carinated bowl sherd has diagonal engraved zones with small excised tick marks (see Figure $3 \mathrm{~h}$ ).

\section{Daub}

Two pieces of daub in the 1970 collection from the Armstrong Landing site indicate that there are burned thatch and grass-covered Caddo structures preserved here. 


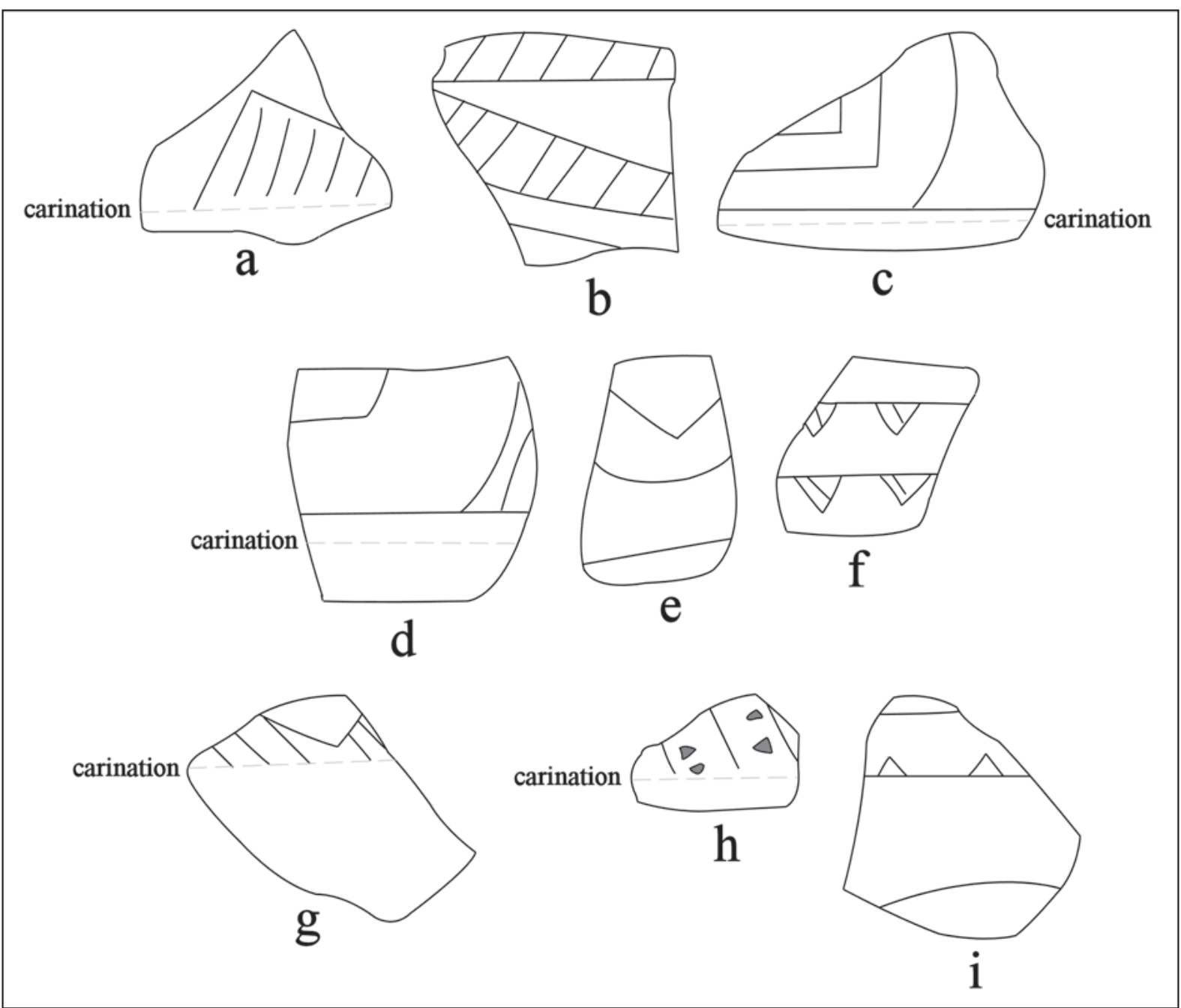

Figure 3. Selected decorative elements on fine ware sherds from the Armstrong Landing site (41CS37): a-h, engraved carinated bowl body sherds; i, engraved bottle sherd.

\section{Chipped Stone Tool}

The sole chipped stone tool in the 1970 collection is a quartzite Yarbrough dart point. This point is evidence that the Armstrong Landing site was used to some extent during the Late Archaic period.

\section{SUMMARY AND CONCLUSIONS}

The Armstrong Landing site is an ancestral Caddo habitation site and possible cemetery on a terrace landform overlooking Lake Wright Patman and the Sulphur River valley in East Texas. The site was first investigated by collectors from the Texarkana area, and although there may be confusion that this site and the nearby Atlanta State Park site (see Harris et al. 1980) are the same site, when it appears likely that they are two different sites, nevertheless there appear to be substantial Caddo archaeological deposits (and burial features) at the Armstrong Landing site.

The sherds from utility ware and fine ware vessels in the TARL ceramic assemblage collected in 1970 by Briggs and Malone (1970) are primarily from grog-tempered vessels. The decorative methods and elements represented in the two wares are consistent with a ca. A.D. 1300-1400 Middle Caddo period occupation in 
the lower Sulphur River basin (see Cliff 1997:Table 1). The Armstrong Landing site warrants further consideration by East Texas Caddo archaeologists.

\section{ACKNOWLEDGMENTS}

Thanks to Jonathan Jarvis at the Texas Archeological Research Laboratory at The University of Texas at Austin for facilitating access to the records and collections from 41CS37. Lance Trask prepared the figures for this article.

\section{REFERENCES CITED}

Bonine, M. L., R. S. Jones, and W. N. Trierweiler

2004 A Cultural Resource Inventory of 1,612 Acres at Lake Wright Patman and Lake Sam Rayburn, Texas. Ecological Communications Corporation, Austin.

Briggs, A. K. and J. Malone

1970 Texarkana Reservoir Enlargement. Archeological Survey Report No. 7. Texas Historical Survey Committee, Austin.

Cliff, M. B.

1997 The Middle Caddoan Period in the Lower Sulphur River Area. Journal of Northeast Texas Archaeology 9:9-16.

Dockall, J. E. and R. C. Fields

2006 Reconnaissance Survey to Assess the Impacts on Archeological Resources of the Proposed Conservation Pool Level Raise at Wright Patman Lake, Bowie and Cass Counties, Texas. Reports of Investigations No. 146. Prewitt and Associates, Inc., Austin.

Harris, R. K., I. M. Harris, and P. Miroir

1980 The Atlanta State Park Site in Northeastern Texas. Louisiana Archaeology 6:231-239.

Suhm, D. A. and E. B. Jelks (editors)

1962 Handbook of Texas Archeology: Type Descriptions. Special Publication No. 1, Texas Archeological Society, and Bulletin No. 4, Texas Memorial Museum, Austin. Reprinted in 2009, Gustav's Library, Davenport, Iowa. 